\title{
THE OCCURRENCE OF DISCRIMINATION IN CROATIA AND CITIZENS' AWARENESS OF ANTI-DISCRIMINATION LEGISLATION
}

Sanja Bježančević, mag. oec.*

\author{
UDK 342.722/.724(497.5) \\ https://doi.org/10.30925/zpfsr.41.3.3 \\ Ur.: 8. rujna 2020. \\ Pr.: 5. listopada 2020. \\ Izvorni znanstveni rad
}

\begin{abstract}
Summary
The principle of non-discrimination is the foundation of the modern system of protection of human rights and freedoms and all the most important international legal treaties governing the protection of human rights proclaim this principle. As one of the fundamental values of the constitutional order of the Republic of Croatia, the prohibition of discrimination is regulated by the Anti-Discrimination Act. Although the legislative framework and mechanisms for protection against discrimination are satisfactory, the reality of discrimination is significantly different. A survey conducted on a sample of 761 adult respondents shows that discrimination is strongly present in Croatian society and that it affects women more often than men. In addition to gender, the sample was stratified by age, level of education, and employment status. These three categories indicated a significant effect on respondents' awareness of the existence of the legislative framework for protection against discrimination. The chi-square test examined the correlation between the respondents' awareness with the legislative framework and mechanisms of protection against discrimination and their treatment as victims of discrimination. The results of the research show that distrust in the system and state institutions is the main reason for nonaction by victims of discrimination, which clearly shows the need for stronger commitment of all stakeholders and the creation of a comprehensive system of protection against discrimination.
\end{abstract}

Keywords: discrimination; non-discrimination principle; anti-discrimination law; protection mechanisms; public awareness of anti-discrimination legislation.

* Sanja Bježančević, mag. oec., Ph.D., candidate, Agricultural Institute Osijek; sanja. bjezancevic@gmail.com. 


\section{INTRODUCTION}

Promoting equality regardless of skin color, sex, language, religion, political or other beliefs, national or social origin, property, birth, education, and social status is one of the fundamental values of the constitutional order of the Republic of Croatia, and the protection against discrimination is regulated by the Anti-Discrimination Act, which was put into effect in 2009. The issue of the protection against discrimination in Croatia was settled after the signing of the Stabilization and Association Agreement between the Republic of Croatia and the European Community, as well as its member states. Despite legal prohibition, discrimination is present in many areas of life and work in today's society.

As an introduction to the results of the research that follows, the first part of this paper provides an overview of the most relevant international legal agreements proclaiming the principle of non-discrimination within the United Nations and the Council of Europe. Next, the paper provides an overview of the competences of the European Union in the fight against discrimination, as well as the legislative and institutional framework for the prohibition of discrimination in Croatia.

The second part of the paper presents the results of the research on the presence of discrimination in the Republic of Croatia, which was conducted by the author from $28^{\text {th }}$ April to $12^{\text {th }}$ May 2020 via computer-mediated communication platforms and social networks and via human rights protection NGOs in Croatia. This paper aims to determine the citizens' recognition of the existence of discrimination through personal experiences and actions if they were victims of discrimination on any of the grounds and their awareness of the legislative framework for protection against discrimination and protection mechanisms. It can be assumed that discrimination is strongly present in Croatian society and that, despite the satisfactory legislative and institutional antidiscrimination framework, the citizens are not familiar enough with the procedure in case of discrimination. It can be assumed that citizens are not sufficiently acquainted with the legislative framework for protection against discrimination or protection mechanisms.

\section{THE PROHIBITION OF DISCRIMINATION IN INTERNATIONAL AND EUROPEAN LAW}

The principle of non-discrimination is the foundation of the modern system of protection of human rights and freedoms. All the most important international legal treaties governing the protection of human rights proclaim this principle. There are a number of historical documents that regulate certain rights, but as these rights are not recognized equally to all, but certain groups of society or community, we cannot discuss the principle of non-discrimination. ${ }^{1}$ The principle of non-discrimination is proclaimed in the United Nations Charter, ${ }^{2}$ and extended in the Universal Declaration

1 See more in: Vesna Barić Punda, "Načelo nediskriminacije - jedno od temeljnih načela zaštite ljudskih prava i sloboda", Zbornik radova Pravnog fakulteta u Splitu 42, 1-2 (2005): 28-29.

2 See: Article 1 and Article 55 of the UN Charter, Croatian translation published in Official 
of Human Rights, ${ }^{3}$ which guarantees rights and freedoms to all ${ }^{4}$ without distinction of any kind, such as race, color, sex, language, religion, political or other opinions, national or social origin, property, birth or other status (Article 2). Although the Universal Declaration was adopted as a resolution without any legal force, its political force was significant to the extent that it served as an example to many future treaties regulating the protection of human rights and freedoms. ${ }^{5}$ The International Covenants of 1966 , both on civil and political rights, ${ }^{6}$ as well as on economic, social and cultural rights, ${ }^{7}$ guarantee the realization of all the rights set forth in them, regardless of differences, i.e. without any discrimination based on race, color, sex, language, religion, political or other belief, national or social origin, property, birth or other circumstances. With a view to adopting the measures necessary to eliminate discrimination against women in all its forms, the Convention on the Elimination of All Forms of Discrimination against Women ${ }^{8}$ has been adopted by the United Nations. According to the Convention, discrimination against women means ${ }^{9}$ any distinction, exclusion or restriction made on the basis of sex which has the effect or purpose of impairing or nullifying the recognition, enjoyment or exercise by women, irrespective of their marital status (Article 1). By the Convention on the Elimination of All Forms of Racial Discrimination, ${ }^{10}$ States Parties have condemned racial discrimination and undertook to pursue a policy of eliminating racial discrimination in all its forms and promoting understanding among all races (Article 2). Racial discrimination refers to any distinction, exclusion, restriction or preference based on race, color, descent, or national or ethnic origin which results in impairing the exercise of human rights and

Gazette, no. 15/1993. See also: Ronald St. J. Macdonald, "The Charter of the United Nations as a world constitution", International Law Studies 75, 1, 13 (2000): 265-266.

3 Universal Declaration of Human Rights, A/RES/217 A (III) of 10 December 1948.

4 Stephanie Farrior, "Color in the Non-Discrimination Provisions of the Universal Declaration of Human Rights and the Two Covenants", Washington University Global Studies Law Review 14, 4 (2015): 753. See also: Barić Punda, "Načelo nediskriminacije - jedno od temeljnih načela zaštite ljudskih prava i sloboda": 30 .

5 Farrior, "Color in the Non-Discrimination Provisions of the Universal Declaration of Human Rights and the Two Covenants": 753.

6 International Covenant on Civil and Political Rights, A/RES/2200 A (XXI) of 16 December 1966. See also: Sarah Joseph, Melissa Castan, The international covenant on civil and political rights: cases, materials, and commentary (Oxford University Press, 2013), 759-831.

7 International Covenant on Economic, Social and Cultural Rights, A/RES/2200 A (XXI) of 16 December 1966. See: Matthew Craven, "Non-Discrimination and Equality", in: Stephanie Farrior (ed.), Equality and Non-Discrimination under International Law (London: Routledge, 2015), 105-148.

8 Convention on the Elimination of All Forms of Discrimination against Women, A/RES/34/180 of 18 December 1979.

9 See in: Simone Cusack, Lisa Pusey, "CEDAW and the Rights to Non-Discrimination and Equality”, Melbourne Journal of International Law 14, 1 (2013): 60-62. See also: Wouter Vandenhole, Non-discrimination and equality in the view of the UN human rights treaty bodies (Oxford: Intersentia, 2005), 24-26.

10 International Convention on the Elimination of All Forms of Racial Discrimination, A/ RES/2106 (XX) of 21 December 1965. See also: Vandenhole, Non-discrimination and equality in the view of the UN human rights treaty bodies, 6-12. 
fundamental freedoms in the political, economic, social, cultural or any other field of public life (Article 1).

The principle of non-discrimination is also a part of the Convention for the Protection of Human Rights and Fundamental Freedoms ${ }^{11}$ of the Council of Europe. The rights and freedoms guaranteed by the Convention must be secured without discrimination on any ground such as sex, race, color, language, religion, national or social origin, belonging to a national minority, political or other opinions, property, birth or any other status (Article 14). While the prohibition of discrimination in Article 14 applies to rights and obligations under the Convention, Protocol No. 12 to the Convention for the Protection of Human Rights and Fundamental Freedoms provides for a general prohibition of discrimination. This guarantees enjoyment of the rights and freedoms set forth in this Convention without discrimination on any ground such as sex, race, color, language, religion, political or other opinions, national or social origin, association with a national minority, property, birth or other status (Article 1. of the Protocol No. 12). As a judicial organ of the Council of Europe, the European Court of Human Rights provides protection against human right violations. It is important to mention that there are a significant number of cases related to the prohibition of discrimination on various grounds ${ }^{12}$ in the jurisprudence of the European Court of Human Rights. ${ }^{13}$ The enjoyment of social rights without any discrimination on grounds of race, color, sex, religion, political opinion, nationality or social origin is secured by the European Social Charter ${ }^{14}$ of the Council of Europe as well. The Social Charter guarantees equal opportunities in terms of employment and profession without discrimination on the grounds of sex (Article 1), which includes access to employment, vocational guidance and retraining, working conditions, including pay, and professional development and promotion.

The jurisdiction of the European Union in the fight against discrimination is ensured by the Treaty of Amsterdam, ${ }^{15}$ which entered into force in $1999 .{ }^{16}$ Member

11 Convention for the Protection of Human Rights and Fundamental Freedoms, Croatian translation published in: Official Gazette - MU no. 18/1997, 6/1999, 14/2002, 13/2003, 9/2005, $1 / 2006,2 / 2010$.

12 See: ECHR, Case of Abdulaziz, Cabales and Balkandali v. The United Kingdom, Application no. 9214/80; 9473/81; 9474/81 (1985); Case of Fretté v. France, Application no. 136515/97 (2002); Case of Glor v. Switzerland, Application no. 13444/04 (2009); Case of Oršuš and others v. Croatia, Application no. 15766/03 (2010). Case of Ramos Nunes De Carvalho E Sá v. Portugal, Application no. 55391/13; 57728/13; $74041 / 13$ (2018).

13 See more in: Snježana Vasiljević, Mario Vinković, Temeljna prava i zabrana diskriminacije u praksi europskih i nacionalnih sudova (Zagreb: Narodne novine, 2019), 55-56, 58, 79-80, 128 130, 132, 155-156.

14 European Social Charter, Croatian translation published in Official Gazette, no. 15/2002.

15 Treaty of Amsterdam Amending the Treaty on European Union, the Treaties Establishing the European Communities and Certain Related Acts, OJ C 340/01, 10 November 1997. See in: Alina Lengauer, "The New General Principle of Non-Discrimination in the EC Treaty as Amended by the Treaty of Amsterdam", Austrian Review of International and European Law 3, 1 (1998): 373-379.

16 Snježana Vasiljević, "Pravni aspekti zaštite manjina u procesu stabilizacije i pridruživanja". U: Pridruživanje Hrvatske Europskoj uniji, Izazovi institucionalnih prilagodbi (Zagreb: Institut za javne financije, Zaklada Friedrich Ebert, 2004), 240. 
States have agreed to take appropriate measures to fight discrimination based on sex, racial or ethnic origin, religion or belief, disability, age or sexual orientation (Article 13). The European Union is founded on the values ${ }^{17}$ of respect for human dignity, freedom, democracy, equality, the rule of law and respect for human rights, including the rights of persons belonging to minorities, in a society in which pluralism, nondiscrimination, tolerance, justice, solidarity and equality of women and men prevail (Article 2). Furthermore, the fight against discrimination based on sex, race, ethnic origin, religion or belief, disability, age or sexual orientation is aimed at in defining and implementation of all policies and activities (Article 10), and any discrimination based on sex, race, skin color, ethnic or social origin, genetic traits, language, religion or belief, political or any other opinions, belonging to a national minority, property, birth, disability, age or sexual orientation, is prohibited (Article 21). The EU has given greater importance to the protection of human rights by adopting the Charter of Fundamental Rights of the European Union, ${ }^{18}$ which became legally binding with the entry into force of the Treaty of Lisbon in 2009. The Charter prohibits any discrimination ${ }^{19}$ on any grounds such as sex, race, color, ethnic or social origin, genetic characteristics, language, religion or belief, political or other opinions, belonging to a national minority, property, birth, disability, age or sexual orientation (Article 21).

\section{THE LEGISLATIVE AND INSTITUTIONAL FRAMEWORK OF ANTI-DISCRIMINATION IN CROATIA}

Although the promotion of equality regardless of skin color, gender, language, religion, political or other beliefs, national or social origin, property, birth, education or social status, is one of the fundamental values contained in the Constitution of the Republic of Croatia, ${ }^{20}$ the issue of protection against discrimination was not regulated until after Croatia signed the Stabilization and Association Agreement. The first laws in Croatia containing provisions on the prohibition of discrimination, and regulating issues of gender equality, protection from domestic violence and issues of same-sex unions $^{21}$ were adopted in 2003. The first law in Croatia ensuring the protection and

17 Treaty of Lisbon amending the Treaty on European Union and the Treaty establishing the European Community, signed at Lisbon, OJ C 306, 17 December 2007. See: Sionaidh DouglasScott, "The European Union and Human Rights after the Treaty of Lisbon", Human Rights Law Review 11, 4 (2011): 650.

18 Charter of Fundamental Rights, OJ C 303/1, 12 December 2007. See also: Koen Leanerts, "Exploring the Limits of the EU Charter of Fundamental Rights", European Constitutional Law Review 8, 3 (2012): 375-376.

19 Douglas-Scott, "The European Union and Human Rights after the Treaty of Lisbon": 651653, See also: Paul Craig, The Lisbon Treaty: law, politics, and treaty reform (Oxford: Oxford University Press, 2010), 193-198.

20 The Constitution of the Republic of Croatia (Ustav Republike Hrvatske), Official Gazette No. 56/1990, 135/1997, 113/2000, 28/2001, 76/10, 5/2014.

21 Gender Equality Act (Zakon o ravnopravnosti spolova), Official Gazette No. 116/2003., Law on Protection against Domestic Violence (Zakon o zaštiti od nasilja u obitelji), Official Gazette No. 116/2003., Life Partnership Act (Zakon o istospolnim zajednicama), Official Gazette No. 116/2003. 
promotion of equality as the highest value of the constitutional order and regulates protection against discrimination entered into force on 1 January $2009 .{ }^{22}$

The Anti-Discrimination $\mathrm{Act}^{23}$ regulates protection against discrimination on the grounds of race or ethnicity, i. e. color, sex, language, religion, age, disability, political or other beliefs, national or social origin, property, trade union membership, education, social position, marital or family status, health status, genetic heritage, gender identity, expression or sexual orientation (Article 1), from harassment and sexual harassment (Article 3), and segregation (Article 5). In the Act, discrimination is considered to be any disadvantage of a person on any of the abovementioned grounds (Article 1), as well as incitement to discrimination and failure to make reasonable adjustments for persons with disabilities (Article 4). In addition to direct and indirect discrimination (Article 2), the Act also regulates more severe forms of discrimination, i. e. the issue of multiple discrimination, repeated and prolonged discrimination (Article 6), and the issue of protection against victimization (Article 7). The Act regulates the actions of national authorities, local and regional government bodies, legal entities with public authority, as well as legal and natural persons in the fields of employment, i.e. work and working conditions, science and education, sports, social security and health care, justice and administration, housing, media and public information, access to goods and services, membership in trade unions, political parties and civil society organizations, and participation in cultural and artistic creation (Article 8).

The Anti-Discrimination Act also regulates the institutional framework for protection against discrimination, and the tasks of the central body responsible for combating discrimination are performed by the Ombudsperson (Article 12). The Ombudsperson ${ }^{24}$ receives complaints of discrimination against all natural and legal persons and provides the necessary information on the rights and obligations of complainants. The Ombudsperson examines individual reports if the court process has not been initiated, and takes actions to eliminate discrimination within the scope of his/her jurisdiction. In addition, the Ombudsperson conducts conciliation proceedings, files criminal charges with the State Attorney's Office related to cases of discrimination, collects data on occurrences of discrimination and warns the public about them. He/she submits annual reports to the Croatian Parliament and proposes legal solutions to the Government of the Republic of Croatia. Furthermore, he/she cooperates with civil society organizations, social partners and organizations for the protection of groups at risk of discrimination, the Council for National Minorities and religious organizations. In his/her work, the Ombudsperson also cooperates ${ }^{25}$ with

22 Snježana Vasiljević, Braslav Balen, "Zakon o suzbijanju diskriminacije u svjetlu europskog prava”, Policija i sigurnost 18, 2 (2009): 214.

23 Anti-discrimination Act (Zakon o suzbijanju diskriminacije), Official Gazette No. 85/2008, $112 / 2012$.

24 See more in: Antonija Petričušić, "Antidiskriminacijska politika kao suplementarni model zaštite prava nacionalnih manjina", Zbornik Pravnog fakulteta u Zagrebu 61, 2 (2011): 665669. See also: Damir Aviani, "Kontrola uprave putem pučkog pravobranitelja”, Zbornik radova Pravnog fakulteta u Splitu 53, 1 (2016): 150.

25 Law on the Ombudsman (Zakon o pučkom pravobranitelju), Official Gazette No. 76/2012. See in: Aviani, "Kontrola uprave putem pučkog pravobranitelja": 141. 
specialized ombudspersons, the Ombudsperson for Children, the Gender Equality Ombudsperson and the Ombudsperson for Persons with Disabilities (Article 1). In his/her work, the Ombudsperson is autonomous and independent and acts under the constitutional and legal provisions and international documents for the protection of human rights to which Croatia is a party and which constitute the internal legislation of Croatia (Article 7). The Ombudsperson's annual reports (Article 16) provide the insight into data on the Ombudsman's Office's activities, whether they are based on citizens' complaints about violations of certain rights or on the Office's own initiative. The reports provide insight into the data structure, i.e. cases the Office has acted upon.

The Anti-Discrimination Act stipulates that anyone who considers that his/ her rights have been violated due to discrimination may seek the protection of that right in the proceedings, including special proceedings, and the court as well as the bodies conducting the proceedings are obliged to act urgently. Proceedings related to protection against discrimination in the field of work and employment are considered to be disputes arising from labor relations (Article 16). If a party claims that his/her right to equal treatment has been violated, he/she is obliged to show probable that discrimination has occurred, and the burden of proof ${ }^{26}$ that there was no discrimination, in that case, lies with the opposing party (Article 20). The Act also allows the participation of third parties in the proceedings, i.e. an organization or institution or association that deals with the protection of the right to equal treatment in relation to groups whose rights are dealt with may join the proceedings as an intervener on the side of the plaintiff (Article 21). The law also allows a joint lawsuit for protection against discrimination (Article 24). The law provides for a fine to sanction discrimination (Article 25-28).

In addition to the Anti-Discrimination Act and the aforementioned Gender Equality Act ${ }^{27}$ the Law on Protection against Domestic Violence and the Life Partnership Act, there are numerous other acts prohibiting discrimination in the Republic of Croatia, such as the Labor Act (Article 7), the Constitutional Act on the Rights of National Minorities (Article 4) and the Criminal Procedure Code (Articles 6 and 13). ${ }^{28}$ The Criminal Code prescribes imprisonment for up to three years for persons who deny, limit or condition another's rights on the grounds of race, ethnicity, color, sex, age, language of religion, national or social origin, political or other beliefs, property, birth, education, social status, marital or family status, disability, genetic inheritance, health, sexual orientation or other grounds (Articles 125 and 126). ${ }^{29}$

26 See more in: Vasiljević, Balen, "Zakon o suzbijanju diskriminacije u svjetlu europskog prava": 216.

27 Gender Equality Act (Zakon o ravnopravnosti spolova), Official Gazette No. 82/2008, 69/2017.

28 Labour Act (Zakon o radu), Official Gazette No. 93/2014, 127/2017, 98/2019.; Act on the Rights of National Minorities (Zakon o pravima nacionalnih manjina), Official Gazette No. 155/2002, 47/2010, 80/2010, 93/2011; Criminal Procedure Code (Zakon o kaznenom postupku), Official Gazette No. 152/2008, 76/2009, 80/2011, 121/2011, 91/2012, 143/2012, 56/2013, 145/2013, 152/2014, 70/2017, 126/2019, 126/2019.

29 Criminal Code (Kazneni zakon), Official Gazette No. 125/11, 144/2012, 56/2015, 61/2015, 101/2017, 118/2018, 126/2019. 


\section{RESEARCH OF THE OCCURRENCE OF DISCRIMINATION IN CROATIA}

A survey including 821 respondents was conducted to determine the occurrence of discrimination and citizens' knowledge of the legislative framework and mechanisms of protection against discrimination in Croatia. This is the first quantitative research on discrimination in the field of social sciences in Croatia and therein lies the scientific contribution of this paper. In addition, the interdisciplinary approach of the conducted research classifies this paper in the field of sociology of law. ${ }^{30}$ Therefore, this research can serve as a good starting point for future research on discrimination as a social problem. 761 respondents completed the survey by answering all the questions. The target population which includes all the adult citizens of the Republic of Croatia is 3681175 inhabitants, according to the most recent census, ${ }^{31}$ which allows the assessment of population parameters with an error of $+/-4.61 \%$ with a degree of certainty of $99 \%$. The survey was conducted by the author from $28^{\text {th }}$ April to $12^{\text {th }}$ May 2020 via the platforms Facebook, Twitter, Whatsapp, Snapchat, Linkedin, Pinterest, Reddit, Tumblr, Skype, Viber, e-mail and other communication platforms, with the help of the human rights protection NGOs. The questionnaire used for data collection consisted of three parts. The first part of the questionnaire contained questions related to socio-demographic characteristics. The second part included questions related to the knowledge of the legislative framework and mechanisms for protection against discrimination in Croatia, while the last part of the questionnaire related to personal experience of respondents on recognizing discrimination and the steps they have undertaken if they said they had been victims of discrimination. The sample was stratified based on gender, age, education and employment status (Table 1). Of the total number of respondents who voluntarily participated in the survey, $60 \%$ were female and $40 \%$ were male. The majority of the respondents were between 31 and 44 years of age, i.e. $43.36 \%$. This was followed by those between 45 and 60 years of age, i.e. $29.57 \%$ of respondents. There were $20.6 \%$ of respondents younger than 30 , and $6.4 \%$ of respondents older than 61 . Almost $53 \%$ of respondents have the tertiary level of education, and the majority of them are employed in the public $(34.30 \%)$ and the private sector $(32.72 \%)$.

This paper determines the occurrence of discrimination in Croatia by researching the personal experiences of the respondents. Previous research on the level of public awareness of the existence of discrimination in Croatia and its

30 See more about sociology of law in: Reza Banakar, "Law through sociology's looking glass: Conflict and competition in sociological studies of law", in: Ann Denis, Devorah KalekinFishman (eds.), The New ISA Handbook in Contemporary International Sociology: Conflict, Competition and Cooperation (Newbury Park Sage, 2009), 64-67.

31 Census of Population, Households and Dwellings 2011, Population by sex and age (Popis stanovništva, kućanstva i stanova 2011. Stanovništvo prema spolu i starosti.), Bureau of Statistics, Zagreb, 2013. 
occurrences was conducted by the Office of the Ombudswoman in 2009, $2012,{ }^{33}$ and $2016 .^{34}$ The aim of the research was to determine the awareness and attitudes about unequal treatment in Croatian society, i.e. citizens' knowledge of the legislative and institutional framework for protection against discrimination and the perception of the occurrence of discrimination. Results on citizens' knowledge of the legislative and institutional framework for protection against discrimination is the only topic where the two research overlap and where they can be compared. Furthermore, this research is preceded by two specific studies on the occurrence of discrimination in specific field and on specific population. The research on the occurrence of discrimination in the Croatian labor market was conducted by the Ivo Pilar Institute of Social Sciences on the population of the unemployed and employers in $2010,{ }^{35}$ and on the youth by the Institute for Labor Market Development in 2012. ${ }^{36}$ These are specific studies focused on a specific area and population.

Table 1 Demographic structure of the respondents

\begin{tabular}{|c|l|c|c|}
\hline \multirow{3}{*}{ Sex } & & Absolute value & Relative value \\
\cline { 2 - 4 } & Male & 302 & 39.68 \\
\hline & Female & 459 & 60.32 \\
\hline \multirow{3}{*}{ Age } & Up to 30 & 157 & 20.63 \\
\cline { 2 - 4 } & From 31 to 44 & 330 & 43.36 \\
\cline { 2 - 4 } & From 45 to 60 & 225 & 29.57 \\
\cline { 2 - 4 } & Over 61 & 49 & 6.44 \\
\hline
\end{tabular}

32 Survey on the attitudes and awareness on discrimination and on discrimination occurrences in 2009 (Istraživanje o stavovima i razini svijesti o diskriminaciji i pojavnim oblicima diskriminacije 2009), The Office of the Ombudswoman of Croatia, Zagreb, 2009.

33 Survey on the attitudes and awareness on discrimination and on discrimination occurrences in 2012 (Istraživanje o stavovima i razini svijesti o diskriminaciji i pojavnim oblicima diskriminacije 2012), The Office of the Ombudswoman of Croatia, Zagreb, 2012.

34 Survey on the attitudes and awareness on discrimination and on discrimination occurrences in 2016 (Istraživanje o stavovima i razini svijesti o diskriminaciji i pojavnim oblicima diskriminacije 2016), The Office of the Ombudswoman of Croatia, Zagreb, 2016.

35 Renata Franc et. al. Ivana Ferić, Stanko Rihtar, Jelena Maričić, Raširenost i obilježja diskriminacije na hrvatskom tržištu rada: Izvješće na temelju ankete među nezaposlenim osobama i ankete među poslodavcima (Zagreb: Institut društvenih znanosti Ivo Pilar, Hrvatski zavod za zapošljavanje, 2010), 12-13.

36 Antonija Bušić Crnković, Ana Frlan Bajer, Lana Načinović, Neudoban položaj: izvještaj o diskriminaciji mladih na hrvatskom tržištu rada (Zagreb: Mreža mladih Hrvatske, 2012). 


\begin{tabular}{|c|l|c|c|}
\hline \multirow{5}{*}{ Education } & Elementary school or less & 12 & 1.58 \\
\cline { 2 - 4 } & High school & 290 & 38.11 \\
\cline { 2 - 4 } & College or University & 400 & 52.56 \\
\cline { 2 - 4 } & Post-graduate degree & 59 & 7.75 \\
\hline & & 43 & 5.65 \\
\hline \multirow{5}{*}{ Status } & Student & 261 & 34.30 \\
\cline { 2 - 4 } & Employed in the public sector & 249 & 32.72 \\
\cline { 2 - 4 } & Employed in the private sector & 69 & 9.07 \\
\cline { 2 - 4 } & Self-employed & 22 & 2.89 \\
\cline { 2 - 4 } & Employed on a non-regular basis & 69 & 9.07 \\
\cline { 2 - 4 } & Unemployed & 48 & 6.31 \\
\cline { 2 - 4 } & Retired & & \\
\hline
\end{tabular}

Source: Author

Of the total number of respondents who participated in the survey, $32.85 \%$ claim that they are familiar with the legislative framework for protection against discrimination in the Republic of Croatia and as many as $41.79 \%$ claim they are partially familiar (Figure 1). A chi-square test with $95 \%$-certainty found that respondents' knowledge of the legislative framework for protection against discrimination was not related to gender, but it was significantly related to their age, education, and employment status. The knowledge of the legislative framework is the highest in the age group of 45 to 60 (36\%), while the knowledge of the respondents in the group over 61 years $(53.06 \%)$, the majority of whom are retired $(60.42 \%)$, is higher than expected. Respondents under the age of 30 (29.30\%) are largely unfamiliar with the legislative framework for protection against discrimination. When it comes to the knowledge of the mechanisms of protection against discrimination, only $16.16 \%$ of the total number of respondents claim to be familiar with them, while $40.60 \%$ claim to be only partially familiar with the mechanisms of protection against discrimination (Fig. 1). The knowledge of the mechanisms of protection against discrimination is in correlation with age and employment status, while the correlation has not been found between gender and education and the knowledge of the protection mechanisms. The majority of students $(41.86 \%)$ and respondents younger than 30 years of age (48.41 $\%$ ) are not familiar with the mechanisms of protection against discrimination. Lack of knowledge on the mechanisms of protection against discrimination is higher than expected among persons employed in the private sector $(41.77 \%)$, and lower than expected among persons employed in the public sector $(27.20 \%)$. 
Figure 1 Respondents' knowledge of the legislative framework and mechanisms of protection against discrimination in the Republic of Croatia

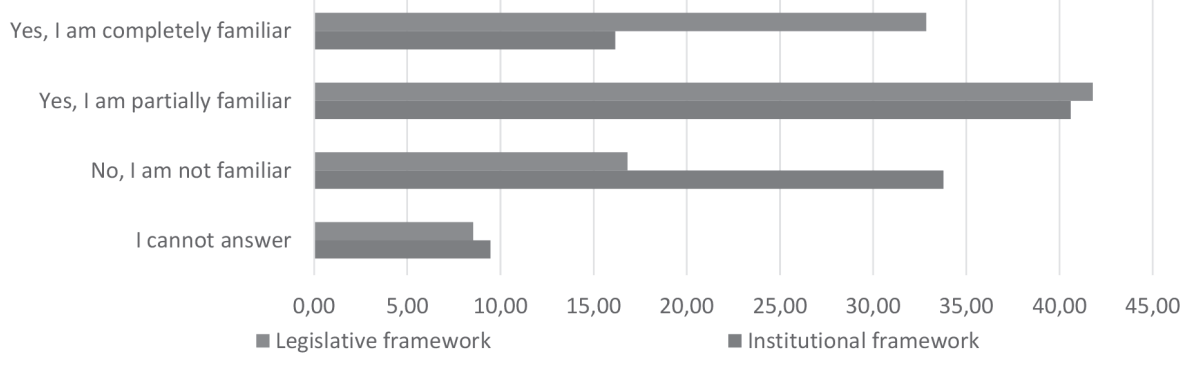

\section{Source: Author}

The chi-square test (95\%-certainty) determined that the respondents' age and employment status affected their level of agreement with the statement that the legislative and institutional framework of the prohibition of discrimination in the Republic of Croatia is satisfactory (Fig. 2). Respondents younger than 30 years of age $(26.75 \%)$ and public sector employees $(12.64 \%)$ are far less familiar with the legislative and institutional framework for protection against discrimination than expected. In the age group of 45 to $60(27.56 \%)$, and among those employed on a non-regular basis $(13.67 \%)$, the majority mostly agree with the statement that the legislative and institutional framework for the prohibition of discrimination in the Republic of Croatia is satisfactory. Respondents employed on a non-regular basis generally disagree with the aforementioned statement $(50 \%)$, which is higher than expected.

Figure 2 Do you agree with the statement that the legislative and institutional framework of the prohibition of discrimination in the Republic of Croatia is satisfactory?

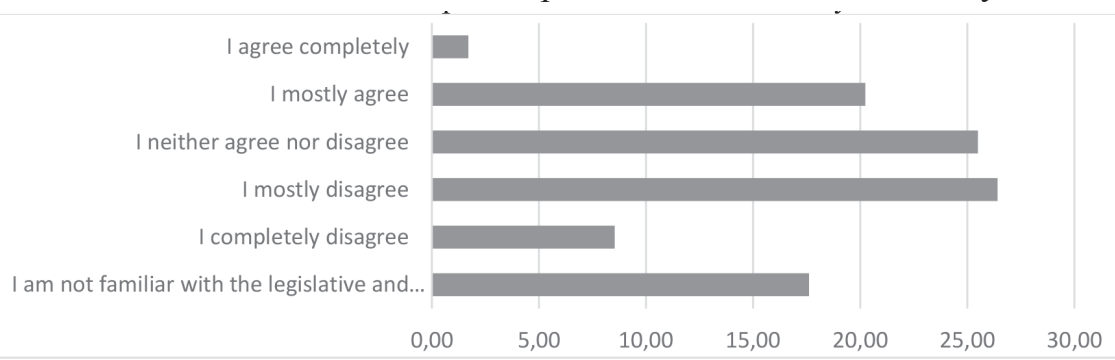

Source: Author

Of the total number of respondents, $67.54 \%$ claimed that they were and probably were victims of discrimination (Fig. 3). The gender proved to be a statistically significant variable for the victims of discrimination, i.e. respondents who thought that they were placed in a less favorable position than another person in a comparable situation. The significance of employment status was at 0.05 , the very verge of the 
statistical significance. Women ( $71 \%$ ) were more likely to be victims of discrimination than men $(62.3 \%)$. The ratio of student respondents claiming they were probably not victims of discrimination was lower than expected $(20.93 \%)$.

Figure 3 Have you ever felt discriminated against or disadvantaged by another person in a comparable situation?

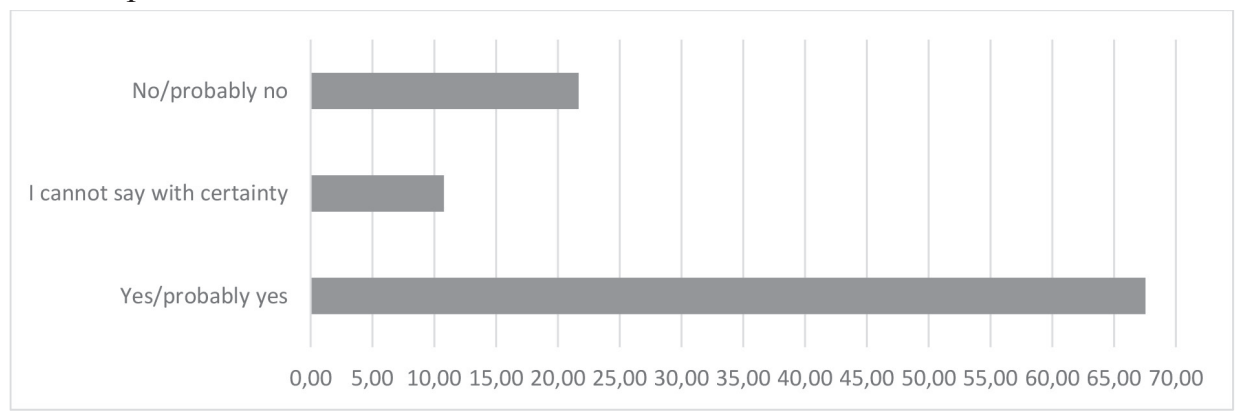

Source: Author

Of the total number of respondents, $43.76 \%$ claim to have experienced discrimination on multiple grounds (Fig. 4). The number of grounds the respondents were discriminated against, i.e. placed in a less favorable position than another person in a comparable situation, was affected by sex, age and employment status. In other words, women were discriminated against more than expected on multiple grounds (47\%), while men were less discriminated against on multiple grounds than expected $(37.42 \%)$. The lowest number of people discriminated against on a single ground was found in the group of youth younger than $30(19.11 \%)$, while the highest number was in the elderly group, older than $61(48.9 \%)$, i.e. in the category of the retired respondents $(52.08 \%)$.

Figure 4 The grounds of discrimination

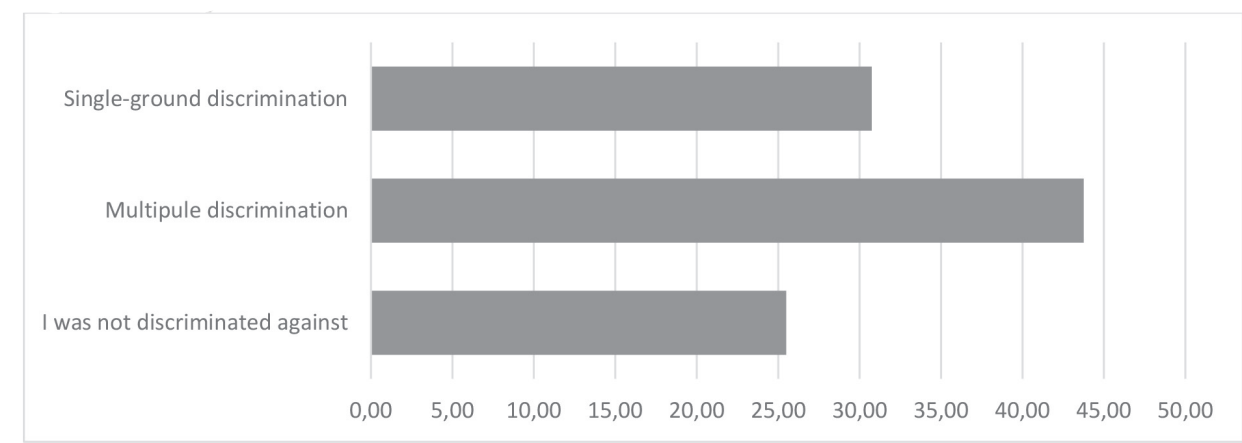

Source: Author 
Of the total number of respondents, $47.44 \%$ claim to have experienced discrimination in only one field (Fig. 5). The chi-square test (95\%-certainty) found that the number of fields in which respondents experienced discrimination was affected by their gender, while their age, education and their employment status had no effect at all. Women were significantly more discriminated against than expected in a single field $(50.54 \%$ ), while men were significantly less discriminated against in a single field ( $42.72 \%)$.

Figure 5 The fields of discrimination

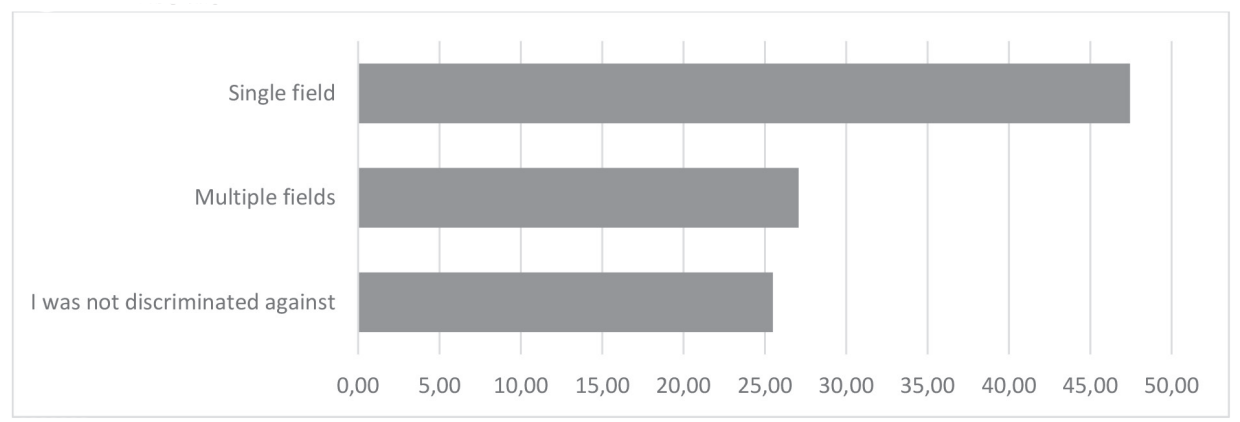

Source: Author

A total of $21.02 \%$ of respondents who experienced discrimination did not tell anyone about it. Of those who did talk about being discriminated against, the largest number $(31.93 \%)$ told family members and/or friends (Fig. 6). Age and gender affected respondents to inform third parties about the discrimination they experienced. Women most often told family members and/or friends about the discrimination they experienced $(35.73 \%)$, while men reported to the media $(1.66 \%)$, which was not expected. Furthermore, persons in the age group over 61 shared their experience of discrimination with the media more often than it was expected (4.8\%), while persons between 45 and 60 years of age contacted a lawyer to report the discrimination they experienced (5.78\%), also more than expected.

Figure 6 With whom did you share your experience of discrimination?

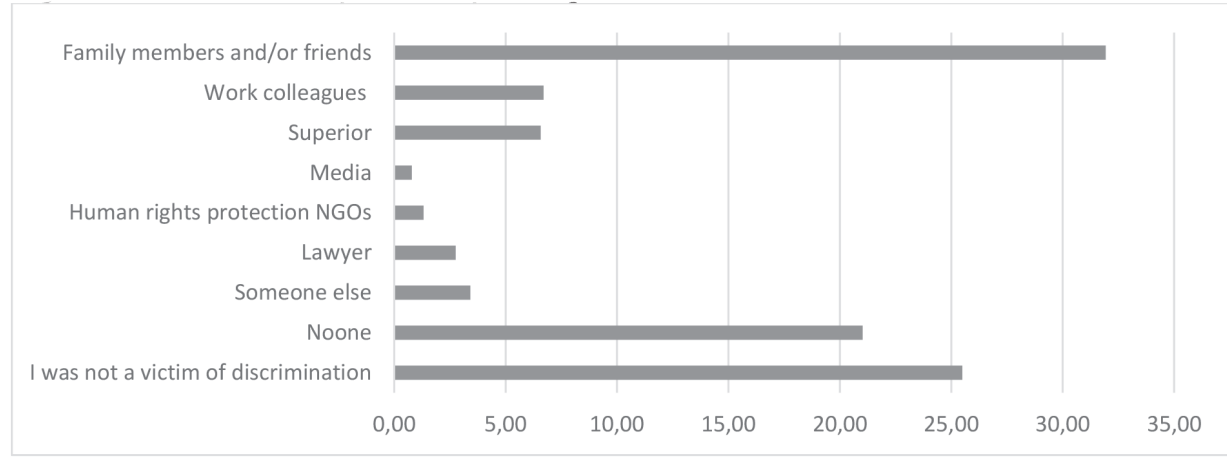

Source: Author 
A total of $37.58 \%$ of respondents did not undertake any action regarding the discrimination they experienced (Fig. 7), while most of those who did do something, complained to someone else $(13.14 \%)$, i.e. within the organization in which they experienced discrimination $(8.67 \%)$ or resigned $(4.73 \%)$. It was determined (95 $\%$-certain chi-square test) that the conduct of respondents who stepped forward as victims of discrimination was affected by age and employment status. Respondents between 45 and 60 years of age filed a lawsuit more often than expected (4.89\%), i.e. they reported discrimination to trade unions more often $(2.67 \%)$. Respondents younger than 30 did not report discrimination to their employers $(0 \%)$. Respondents employed in the public sector were the least likely of all the categories covered by the survey to respond by resigning $(1.92 \%)$.

Figure 7 Actions undertaken in case of discrimination

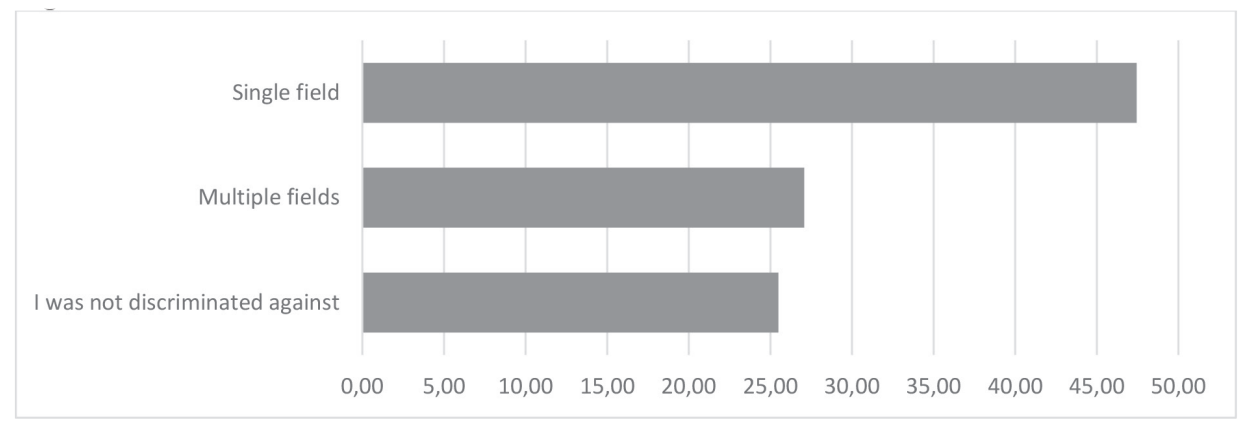

Source: Author

Of the number of respondents who consider themselves victims of discrimination on any of the grounds (286 respondents), who did not file a complaint or did not act on discrimination (Fig. 8), most of them cite the lack of trust that reporting will solve the problem $(81 \%)$ as well as the distrust in the system $(34.97 \%)$. The reason for not filing a complaint was affected by gender ( $95 \%$-certain chi-square test). As reasons for not acting on discrimination men most commonly cited the distrust in the system $(42.34 \%)$, while women cited that reporting would not solve the problem (44\%). Both men and women almost equally chose fear of judgment and misunderstanding of the environment ( $7.21 \%$ men and $7.43 \%$ women) as the reason for not acting on discrimination. Women chose a lack of knowledge of the protection mechanisms less often than expected, while men chose the same reason more often than it was expected. 
Figure 8 Reasons for not acting on discrimination

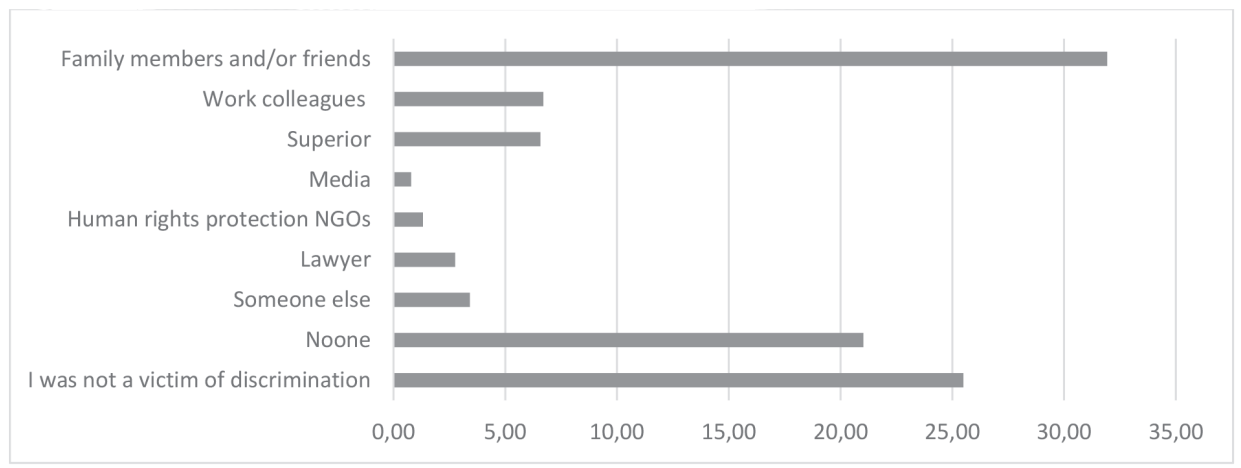

Source: Author

When asked if they would do something if they had reasonable doubt of discrimination against other persons, $33.90 \%$ of the total number of respondents could not determine with certainty. A total of $24.70 \%$ of respondents would do something and $32.59 \%$ would probably do something (Fig. 9). Respondents' responses were not affected by any socio-demographic variable, i.e. they would equally undertake action independent of gender, age, education, or employment status.

Figure 9 Reporting reasonable doubt of discrimination of third parties (part 1)

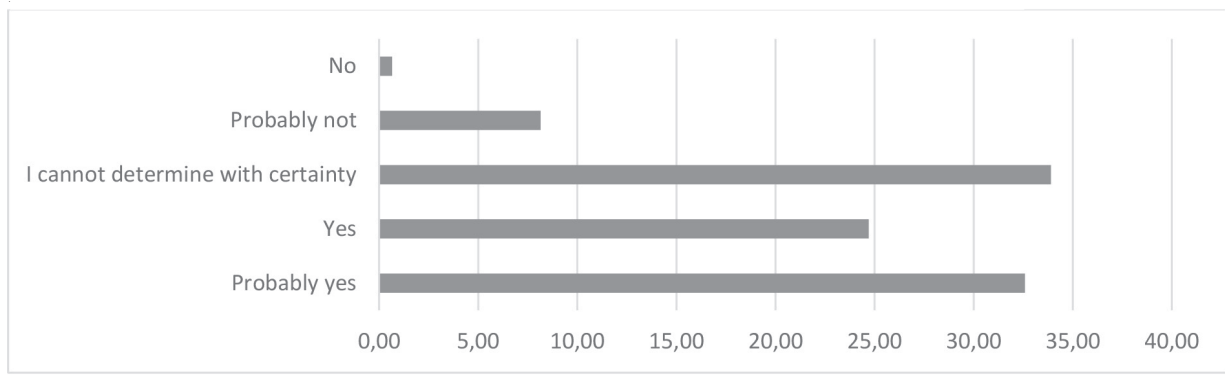

Source: Author

When asked whom they would turn to in case of reasonable doubt of discrimination against other people, $26.54 \%$ did not know, and $18.79 \%$ of respondents would contact the human rights protection NGO (Fig. 10). Only $3.42 \%$ of respondents would turn to the State Attorney. The respondents' choice of action is affected by gender, age, and employment status (chi-square test). For the most part, women would turn to the human rights protection NGO (20.92\%), while only $3.05 \%$ would talk to the police and $6.75 \%$ to the media, which is less than expected. The majority of men would also turn to the human rights NGO $(15.56 \%)$ and more than expected would talk to the police $(8.28 \%)$ and the media $(14.57 \%)$. Respondents younger than 30 would most often turn to the Office for Human Rights and the Rights of National Minorities of the Republic of Croatia (17.83\%), and less than expected to the human rights protection 
NGO $(10.19 \%)$ and the media $(4.46 \%)$. Contacting the human rights protection NGO is the most common answer for respondents between 31 and 44 years of age $(17.88$ \%), those between 45 and 60 (24.89\%), and respondents older than 61 (24.49\%). Respondents employed in the private sector would more often than expected turn to a lawyer $(2.51 \%)$ in case of reasonable suspicion of discrimination against other persons, while pensioners would turn to the State Attorney more often than expected $(10.42 \%)$.

Figure 10 Reporting reasonable doubt of discrimination of third parties (part 2)

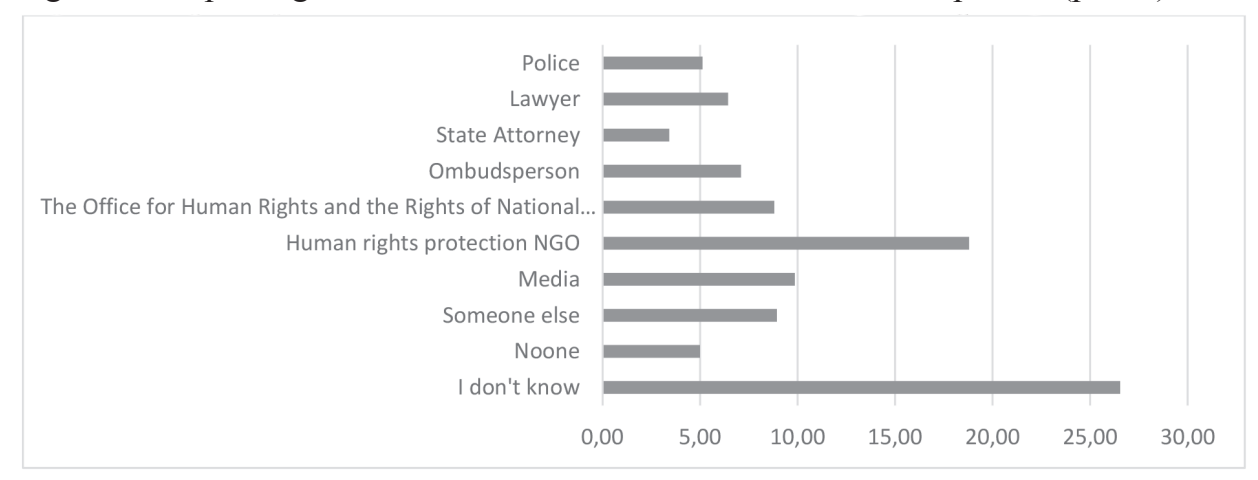

Source: Author

When it comes to raising awareness of the importance of non-discrimination in society (Fig. 11), a total of $33.11 \%$ of respondents believe that human rights protection NGOs contribute the most, followed by $19.71 \%$ of those who believe it is the media and $13.14 \%$ educational institutions. A total of $15.64 \%$ cannot determine with certainty who contributes the most to raising awareness, while $2.23 \%$ believe that it is the Office of the Ombudswoman. Only a small number of respondents believe that the Croatian Parliament $(0.79 \%)$ contributes to raising awareness of the importance of anti-discrimination, and almost $10 \%$ answered they didn't know. Respondents' attitudes on who contributes to raising awareness of the importance of combating discrimination were influenced by age and employment status. Respondents over the age of 61 more often than expected chose the Croatian Parliament as an institution that contributes to raising awareness of the importance of combating discrimination, while retired respondents more often than expected chose the Office of the President, and those employed on a non-regular basis chose the Government as one contributing the most to raising awareness on combating discrimination. 
Figure 11 Raising awareness on the importance of combating discrimination

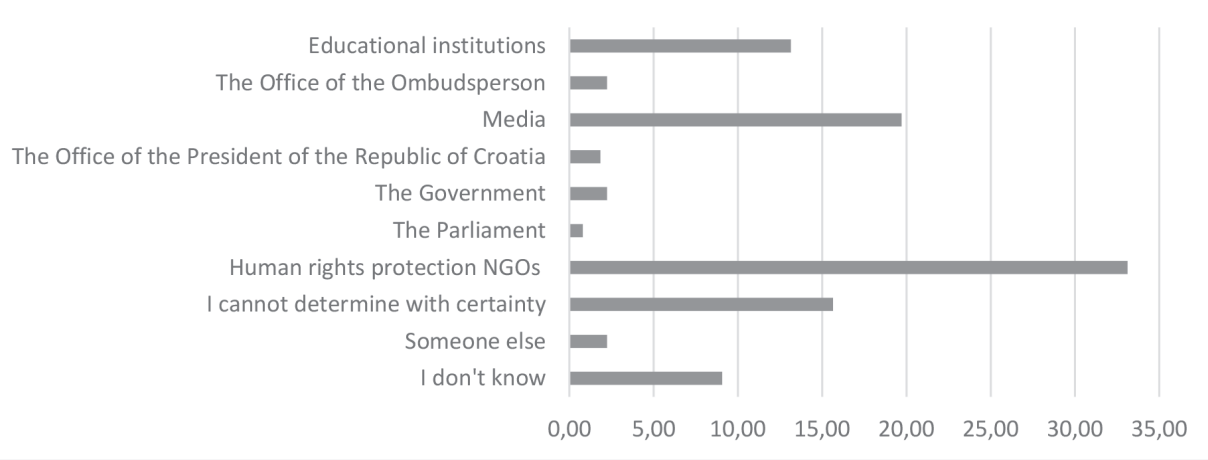

Source: Author

A chi-square test was done in order to determine the correlation between the knowledge of the legislative framework for protection against discrimination and acting on discrimination and the correlation between the knowledge of the institutional framework and acting on discrimination (Table 2). The null hypothesis which assumes the independence of the knowledge of the legislative framework for protection against discrimination and action on the issue of discrimination is rejected at the level of 95 $\%$, i.e. it cannot be accepted. This leads to the conclusion that people who are familiar with the legislative framework of anti-discrimination are more likely to act on the occurrence of discrimination. The null hypothesis which assumes the independence of the knowledge of the mechanisms of protection against discrimination and acting on discrimination is rejected at the level of $95 \%$ as well, i.e. it cannot be accepted with any level of significance and the chi-square test. This means that people who are familiar with the mechanisms of protection against discrimination are more likely to act on the occurrence of discrimination than people who are not familiar with the stated mechanisms.

Table 2 Contingency table examining the relationship between the knowledge of the legislative and institutional framework and acting on discrimination

\begin{tabular}{|l|c|c|c|}
\hline & \multicolumn{3}{|c|}{ Acting on discrimination } \\
\hline $\begin{array}{l}\text { The knowledge of the legislative framework for } \\
\text { protection against discrimination }\end{array}$ & Yes & No & Total \\
\hline Yes and partially yes & 229 & 208 & 437 \\
\hline I cannot answer with certainty & 15 & 29 & 44 \\
\hline No & 36 & 49 & 85 \\
\hline Total & 280 & 286 & 566 \\
\hline$\chi^{2}=7.39 \mathrm{p}=0.02<0.05$ & & & \\
\hline
\end{tabular}




\begin{tabular}{|l|c|c|c|}
\hline & \multicolumn{2}{|c|}{ Acting on discrimination } \\
\hline $\begin{array}{l}\text { The knowledge of the protection mechanisms } \\
\text { against discrimination }\end{array}$ & Yes & No & Total \\
\hline Yes and partially yes & 183 & 149 & 332 \\
\hline I cannot answer with certainty & 20 & 29 & 49 \\
\hline No & 77 & 108 & 185 \\
\hline Total & 280 & 286 & 566 \\
\hline$\chi^{2}=10.3 p=0.006<0.05$ & & & \\
\hline
\end{tabular}

Source: Author

The results show that women are more interested in participating in the survey on discrimination, but the knowledge of the legislative and institutional framework for protection against discrimination was not affected by gender. Gender proved to be a statistically significant variable in case of the occurrence of discrimination and the grounds of discrimination. Women are more likely to be discriminated against than men. Of the total number of women who participated in the survey, $71 \%$ claimed to have been and/or likely have been victims of discrimination. Almost half of the female respondents were discriminated against on multiple grounds and a quarter of them in multiple fields. Part of the problem lies in the fact that a woman's position is still affected by social influences, traditional roles, and prejudice based on biological gender differences. When it comes to men, about a third of respondents claimed to have been discriminated against on multiple grounds and about a quarter in multiple fields. Women most often talk to family members and/or friends about discrimination and file complaints within the organization in which they have experienced discrimination, but almost $40 \%$ of them do nothing if discriminated against. This is the result of the belief that reporting will not solve the problem.

The age proved to be an important factor when it comes to the knowledge of the legislative and institutional framework for protection against discrimination, i.e. older respondents stated they had more knowledge of the framework for protection against discrimination. Furthermore, older respondents disagreed more with the claim that the legislative and institutional framework is satisfactory. The reasons for insufficient knowledge of the legislative framework for protection against discrimination among the younger population can be found in the underrepresentation of this topic in formal and non-formal education, their lack of interest in the topic, but also the fact that many of them cannot recognize discrimination or have not encountered it due to not being independent in fields of work or housing. As the age of the respondents increases, so does the number of victims of discrimination and the number of victims of single-ground discrimination, while the number of victims of discrimination on multiple grounds decreases. If we take into account the fact that protection against discrimination was regulated only ten years ago and that concepts such as multiple or repeated discrimination are relatively new in the Croatian public space, such a state 
is expected. The data shows that younger respondents act on discrimination less often than older respondents, which is also related to their lack of knowledge on the topic and protection mechanisms. The youngest group of respondents in this survey $(>30$ years old) are the least likely to act if discriminated against. All groups of respondents act approximately similarly in case of discrimination of third parties.

The education of the respondents proved to be a statistically significant variable only in the issue of the knowledge of the legislative framework of protection against discrimination. The knowledge of the legislative framework is significantly higher than expected among respondents who completed postgraduate education. There is a significantly high number of respondents who completed secondary education that cannot answer with certainty whether they are familiar with the legislative framework for protection against discrimination. In other words, the knowledge of the legislative framework grows with the degree of education. The knowledge of the mechanisms of protection is approximately equal among respondents at all levels of education, but slightly higher among people who completed postgraduate studies. This confirms the hypothesis of the research on the level of awareness of discrimination of the Office of the Ombudswoman that persons with lower education are more often less familiar with this topic and the framework of protection. Acting on discrimination is similar for respondents of all levels of education, but only slightly lower in high-educated people. The reason can be found in better knowledge of the legislative framework, i.e. knowing what discrimination entails. This results in easier recognition of discrimination and consequently recognizing whether a certain treatment is indeed discrimination. Furthermore, people with a postgraduate degree most often state that they would do something in case of discrimination against other people.

Respondents' working status also affected their knowledge of the legislative and institutional framework for protection against discrimination. Retired persons and employees in the public sector more often claim to be familiar with the legislative and institutional framework of protection against discrimination, and equally declare themselves as victims of discrimination. More often, only the unemployed and currently self-employed do so. When it comes to acting on reasonable doubt of discrimination against third parties, there are differences among groups of respondents according to their employment status. Most often, the self-employed and those employed on a non-regular basis are ready to act on discrimination, while unemployed and persons employed in the private sector are less likely to act.

\section{CONCLUSION}

Acting on discrimination is related to the knowledge of the legislative framework and mechanisms for protection against discrimination. The results of the survey show that the activities related to the reporting of discrimination stems from the knowledge of the legislative framework and the protection mechanisms available to victims of discrimination, which is currently insufficient. That is why it is necessary to systematically inform and educate citizens about the meaning of discrimination, but also about the harmfulness of discrimination for both the individual who suffers 
discrimination and for society as a whole. It is particularly necessary to pay attention to the youth and people of lower education levels as they are the least familiar with the issues related to discrimination. Formal and non-formal education and powerful public campaigns at the national level are a way to raise awareness of the importance of combating discrimination and promoting equality. This is confirmed by the fact that human rights non-governmental organizations that conduct public information campaigns are recognized as the organizations that contribute the most to the development of awareness of the importance of non-discrimination in society. With the aim of recognizing discrimination and empowering the youth to act on it and suppress their fear of victimization or judgment of the environment, it is necessary to pay attention to the topic of discrimination through formal education and interdisciplinary approach in the existing educational system.

Although the legislative and institutional framework for protection against discrimination is satisfactory, discrimination is strongly present in Croatia, but citizens' awareness of the necessity of reporting discrimination is not satisfactory. In other words, initiating proceedings related to discrimination depends exclusively on the victim of discrimination. That is why, in addition to informing about what discrimination is and the right to non-discrimination, the empowerment of potentially discriminated groups (women, national minorities, religious minorities, same-sex orientation people, and others) is necessary.

As the main reasons for non-action related to discrimination are distrust in the system and the belief that reporting discrimination to the authorities will not solve the problem, it is necessary to continuously educate civil and judicial officials and officials on combating discrimination and equal treatment of minority and marginalized groups. In addition, a systematic approach is needed to monitor the occurrence of discrimination, as well as its suppression, and the national antidiscrimination plan with concrete measurable activities and the central state body for combating discrimination need to ensure greater media space and clarity. All these elements, from preventive mechanisms and education to acting on discrimination and its suppression, are necessary to build a system of anti-discrimination which, with an interdisciplinary approach and inclusion of all social groups and consensus of all potential stakeholders, is a long-term way to create a tolerant and inclusive society which respects rights and equality of all its citizens.

\section{Books and articles:}

\section{BIBLIOGRAPHY}

1. Aviani, Damir. "Kontrola uprave putem pučkog pravobranitelja". Zbornik radova Pravnog fakulteta u Splitu 53, 1 (2016): 139-164.

2. Banakar, Reza. "Law through sociology's looking glass: Conflict and competition in sociological studies of law". In: The New ISA Handbook in Contemporary International Sociology: Conflict, Competition and Cooperation, (eds.) Ann Denis, Devorah KalekinFishman, 58-74. Newbury Park: Sage, 2009.

3. Barić Punda, Vesna. "Načelo nediskriminacije - jedno od temeljnih načela zaštite ljudskih prava i sloboda”. Zbornik radova Pravnog fakulteta u Splitu 42, 2 (2005): 27-42. 
4. Bušić Crnković, Antonija, Ana Frlan Bajer, Lana Načinović. Neudoban položaj: izvještaj o diskriminaciji mladih na hrvatskom tržištu rada. Zagreb: Mreža mladih Hrvatske, 2012.

5. Craig, Paul. The Lisbon Treaty: law, politics, and treaty reform. Oxford: Oxford University Press, 2010.

6. Craven, Matthew. "Non-Discrimination and Equality". In: Equality and NonDiscrimination under International Law, Stephanie Farrior (ed.), 105-148. London: Routledge, 2015.

7. Cusack, Simone, Lisa Pusey. "CEDAW and the Rights to Non-Discrimination and Equality". Melbourne Journal of International Law 14, 1 (2013): 54-92.

8. Douglas-Scott, Sionaidh. "The European Union and Human Rights after the Treaty of Lisbon". Human Rights Law Review 11, 4 (2011): 645-682.

9. Farrior, Stephanie. "Color in the Non-Discrimination Provisions of the Universal Declaration of Human Rights and the Two Covenants". Washington University Global Studies Law Review 14, 4 (2015): 751-777.

10. Franc, Renata, Ivana Ferić, Stanko Rihtar, Jelena Maričić. Raširenost i obilježja diskriminacije na hrvatskom tržištu rada: Izvješće na temelju ankete među nezaposlenim osobama $i$ ankete među poslodavcima. Zagreb: Institut društvenih znanosti Ivo Pilar, Hrvatski zavod za zapošljavanje, 2010.

11. Joseph, Sarah, Melissa Castan. The international covenant on civil and political rights: cases, materials, and commentary. Oxford: Oxford University Press, 2013.

12. Leanerts, Koen. "Exploring the Limits of the EU Charter of Fundamental Rights". European Constitutional Law Review 8, 3 (2012): 375-376.

13. Lengauer, Alina. "The New General Principle of Non-Discrimination in the EC Treaty as amended by the Treaty of Amsterdam". Austrian Review of International and European Law 3, 1 (1998): 369-395.

14. Macdonald, Ronald St J. "The Charter of the United Nations as a world constitution". International Law Studies 75, 1, 13 (2000): 263-300.

15. Petričušić, Antonija. "Antidiskriminacijska politika kao suplementarni model zaštite prava nacionalnih manjina". Zbornik Pravnog fakulteta u Zagrebu 61, 2 (2011): 643-674.

16. Vandenhole, Wouter. Non-discrimination and equality in the view of the UN human rights treaty bodies. Oxford: Intersentia, 2005.

17. Vasiljević, Snježana. "Pravni aspekti zaštite manjina u procesu stabilizacije i pridruživanja" Pridruživanje Hrvatske Europskoj uniji, Izazovi institucionalnih prilagodbi. Zagreb: Institut za javne financije, Zaklada Friedrich Ebert, 2004: 235-257.

18. Vasiljević, Snježana, Braslav Balen. "Zakon o suzbijanju diskriminacije u svjetlu europskog prava”. Policija i sigurnost 18, 2 (2009): 213-221.

19. Vasiljević, Snježana, Mario Vinković. Temeljna prava i zabrana diskriminacije u praksi europskih i nacionalnih sudova. Zagreb: Narodne novine, 2019.

Legal sources:

1. Act on the Rights of National Minorities (Zakon o pravima nacionalnih manjina), Official Gazette No. 155/2002, 47/2010, 80/2010, 93/2011.

2. Anti-discrimination Act (Zakon o suzbijanju diskriminacije), Official Gazette No. $85 / 2008,112 / 2012$.

3. Charter of Fundamental Rights, OJ C 303/1, 12 December 2007.

4. Charter of the United Nations, Croatian translation published in Official Gazette, no. $15 / 1993$.

5. Convention for the Protection of Human Rights and Fundamental Freedoms, Croatian translation published in: Official Gazette - MU 18/1997, 6/1999, 14/2002, 13/2003, 9/2005, 1/2006, 2/2010.

6. Convention on the Elimination of All Forms of Discrimination against Women, A/ RES/34/180 of 18 December 1979. 
7. Criminal Code (Kazneni zakon), Official Gazette No. 125/11, 144/2012, 56/2015, 61/2015, 101/2017, 118/2018, 126/2019.

8. Criminal Procedure Code (Zakon o kaznenom postupku), Official Gazette No. 152/2008, 76/2009, 80/2011, 121/2011, 91/2012, 143/2012, 56/2013, 145/2013, 152/2014, 70/2017, $126 / 2019,126 / 2019$.

9. ECHR, Case of Abdulaziz, Cabales and Balkandali v. The United Kingdom, Application no. 9214/80; 9473/81; 9474/81 (1985).

10. ECHR, Case of Fretté v. France, Application no. 136515/97 (2002).

11. ECHR, Case of Glor v. Switzerland, Application no. 13444/04 (2009).

12. ECHR, Case of Oršuš and others v. Croatia, Application no. 15766/03 (2010).

13. ECHR, Case of Ramos Nunes De Carvalho E Sá v. Portugal, Application no. 55391/13; 57728/13; 74041/13 (2018).

14. European Social Charter, Croatian translation published in Official Gazette no. 15/20002.

15. Gender Equality Act (Zakon o ravnopravnosti spolova), Official Gazette No. 116/2003.

16. Gender Equality Act (Zakon o ravnopravnosti spolova), Official Gazette No. 82/2008, 69/2017.

17. International Covenant on Civil and Political Rights, A/RES/2200 A (XXI) of 16 December 1966.

18. International Covenant on Economic, Social and Cultural Rights, A/RES/2200 A (XXI) of 16 December 1966.

19. International Convention on the Elimination of All Forms of Racial Discrimination, A/ RES/2106 (XX) of 21 December 1965.

20. Labour Act (Zakon o radu), Official Gazette No. 93/2014, 127/2017, 98/2019.

21. Law on Protection against Domestic Violence (Zakon o zaštiti od nasilja u obitelji), Official Gazette No. 116/2003.

22. Law on the Ombudsman (Zakon o pučkom pravobranitelju), Official Gazette No. 76/2012.

23. Life Partnership Act (Zakon o istospolnim zajednicama), Official Gazette No. 116/2003.

24. The Constitution of the Republic of Croatia (Ustav Republike Hrvatske), Official Gazette No. 56/1990, 135/1997, 113/2000, 28/2001, 76/10, 5/2014.

25. Treaty of Amsterdam Amending the Treaty on European Union, the Treaties Establishing the European Communities and Certain Related Acts, OJ C 340/01, 10 November 1997.

26. Treaty of Lisbon amending the Treaty on European Union and the Treaty establishing the European Community, OJ C 306, 17 December 2007.

27. Universal Declaration of Human Rights, A/RES/217 A (III) of 10 December 1948.

\section{Official publications:}

1. Census of Population, Households and Dwellings 2011, Population by sex and age (Popis stanovništva, kućanstva i stanova 2011. Stanovništvo prema spolu i starosti.), Bureau of Statistics, Zagreb, 2013.

2. Survey on the attitudes and awareness on discrimination and on discrimination occurrences in 2009 (Istraživanje o stavovima i razini svijesti o diskriminaciji i pojavnim oblicima diskriminacije 2009), The Office of the Ombudswoman of Croatia, Zagreb, 2009.

3. Survey on the attitudes and awareness on discrimination and on discrimination occurrences in 2012 (Istraživanje o stavovima i razini svijesti o diskriminaciji i pojavnim oblicima diskriminacije 2012), The Office of the Ombudswoman of Croatia, Zagreb, 2012.

4. Survey on the attitudes and awareness on discrimination and on discrimination occurrences in 2016 (Istraživanje o stavovima i razini svijesti o diskriminaciji i pojavnim oblicima diskriminacije 2016), The Office of the Ombudswoman of Croatia, Zagreb, 2016. 


\section{Sanja Bježančević*}

Sažetak

\section{POJAVNOST DISKRIMINACIJE U HRVATSKOJ I UPOZNATOST GRAĐANA S ANTIDISKRIMINACIJSKIM ZAKONODAVSTVOM}

Načelo zabrane diskriminacija temelj je suvremenog sustava zaštite ljudskih prava i sloboda i svi najvažniji međunarodno pravni ugovori koji uređuju pitanje zaštite ljudskih prava proklamiraju ovo načelo. Kao jedna od temeljnih vrednota ustavnog poretka Republike Hrvatske, zabrana diskriminacije uređena je Zakonom o suzbijanju diskriminacije. Iako su zakonodavni okvir i mehanizmi zaštite od diskriminacije zadovoljavajući, stanje diskriminacije bitno je drugačije. Istraživanje provedeno na uzorku od 761 punoljetnom ispitaniku pokazuje da je diskriminacija u hrvatskom društvu snažno prisutna te da češće pogađa osobe ženskog spola. Osim po spolu, uzorak je stratificiran i po dobi, stupnju obrazovanja te njihovom radnom statusu i upravo te tri kategorije pokazuju značajan utjecaj na upoznatost ispitanika sa postojanjem zakonodavnog okvira zaštite od diskriminacije. Hi-kvadrat testom ispitana je veza između upoznatosti ispitanika sa zakonodavnim okvirom i mehanizmima zaštite od diskriminacije te njihovim postupanjem kao žrtava diskriminacije. Iz rezultata istraživanja je vidljivo da je nepovjerenje u sustav i institucije države glavni razlog nepostupanja žrtava diskriminacije što jasno pokazuje potrebu snažnijeg zalaganja svih dionika i kreiranje cjelovitog sustava zaštite od diskriminacije.

Ključne riječi: diskriminacija, načelo zabrane diskriminacije; antidiskriminacijsko pravo; mehanizmi zaštite; javna svijest o antidiskriminacijskom zakonodavstvu.

Zussamenfassung

\section{ERSCHEINUNG DER DISKRIMINIERUNG IN KROATIEN UND VERTRAUTHEIT DER BÜRGER MIT ANTIDISKRIMINIERUNGSGESETZGEBUNG}

Der Diskriminierungsverbotgrundsatz ist die Grundlage des modernen Schutzes der Menschenrechte und Freiheiten und all die wichtigsten völkerrechtlichen Verträge die den Schutz der Menschenrechte regeln verkünden diesen Grundsatz.

* Sanja Bježančević mag. oec., doktorantica, Poljoprivredni institut Osijek; sanja.bjezancevic@ gmail.com. 
Als ein der Grundwerte der Verfassungsordnung der Republik Kroatien ist das Diskriminierungsverbot durch das Gesetz zur Bekämpfung der Antidiskriminierung geregelt. Obwohl der gesetzliche Rahmen und Schutzmechanismen zufriedenstellend sind, sei der Zustand der Diskriminierung besorgniserregend. Eine Untersuchung von 761 Volljährigen zeigt, dass die Diskriminierung in der kroatischen Gesellschaft stark präsent ist und häufiger weibliche Bevölkerung betrifft. Außer nach Geschlecht wurde die Untersuchung nach Alter, Bildungsgrad und Arbeitsstatus durchgeführt und diese drei Kategorien zeigen geradezu einen wesentlichen Einfluss auf den Grad der Vertrautheit der Befragten mit der Gesetzgebung für den Schutz vor Diskriminierung. Anhand von HI-Quadrat Test wurde die Beziehung zwischen den Befragten mit dem gesetzlichen Rahmen und Schutzmechanismen vor Diskriminierung und ihrer Behandlung als Diskriminierungsopfer überprüft. Die Ergebnisse deuten auf fehlendes Vertrauen in die staatlichen Institutionen als Hauptgrund dafür, dass die Diskriminierungsopfer keine Verfahren in die Wege leiten, weshalb ein stärkerer Einsatz seitens aller Teilnehmer notwendig ist, um ein einheitliches System des Diskriminierungsschutzes zu schaffen.

Schlüsselwörter: Diskriminierung; Grundsatz des Diskriminierungsverbots; Antidiskriminierungsrecht; Schutzmechanismen; öffentliches Bewusstsein zur Antidiskriminierungsgesetzgebung.

Riassunto

\section{IL FENOMENO DELLA DISCRIMINAZIONE IN CROAZIA E LA COSCIENZA DEI CITTADINI DELLA LEGISLAZIONE ANTIDISCRIMINATORIA}

Il principio di non discriminazione sta alla base del sistema moderno di protezione dei diritti umani, delle libertà e di tutti i trattati internazionali più importanti governati dalla protezione dei diritti umani che proclamano questo principio. Come uno dei valori fondamentali dell'ordinamento costituzionale della Repubblica di Croazia, il divieto di discriminazione è regolato dalla Legge sul divieto di discriminazione. Nonostante il quadro normativo ed i meccanismi per la protezione contro la discriminazione siano soddisfacenti, la realtà è ben diversa. Il sondaggio condotto su un campione di 761 adulti intervistati dimostra che la discriminazione è fortemente presente nella società croata e che colpisce più spesso le donne rispetto ai maschi. In aggiunta al genere, il campione è stato stratificato secondo l'età, il livello di educazione e lo stato occupazionale. Queste tre categorie indicano un effetto significante sulla coscienza degli intervistati dell'esistenza del quadro normativo per la protezione conto la discriminazione. Il test del chi-quadro ha esaminato la correlazione tra la coscienza degli intervistati insieme al quadro normativo con i meccanismi per la protezione contro la discriminazione ed il trattamento di essi come vittime della discriminazione. 
I risultati della ricerca dimostrano che la mancanza di fiducia nel sistema e nelle istituzioni statali sono le ragioni principali dell'atteggiamento passivo delle vittime di discriminazione, le quali mettono chiaramente in evidenza la necessità di un notevole impegno di tutte le parti interessate e la creazione di un sistema di protezione contro la discriminazione comprensibile.

Parole chiave: discriminazione; principio di non discriminazione; diritto antidiscriminatorio; meccanismi di protezione; coscienza pubblica della legislazione antidiscriminatoria. 
